\title{
Identifikasi Ekologi Sarang Elang Jawa (Nisaetus bartelsi) Di Taman Nasional Gunung Halimun Salak, Resort Gunung Salak I
}

\section{(Ecological Identification of Javan Hawk Eagle (Nisaetus bartelsi) in the Sukamantri Camping Ground Area, Mount Salak I Resort)}

\author{
Ratih Iskandar $^{{ }^{*}}$, Dewi Elfidasari ${ }^{1}$, Pairah $^{2}$ \\ ${ }^{1}$ Universitas Al Azhar Indonesia \\ Program Studi (Bioteknologi),Fakultas Sains dan Teknologi (FST) \\ Jl. Sisingamangraja, Kby. Baru, Jakarta, Indonesia. 12110 \\ ${ }^{2}$ Balai Taman Nasional Gunung Halimun Salak \\ Jl. Raya Cipanas, Kabandungan,Sukabumi, Jawa Barat 43368 \\ *Email: Ratihrsn14@gmail.com
}

(Article History: Received November 11, 2020; Revised January 5, 2021; Accepted 28 February 2021)

\begin{abstract}
ABSTRAK
Salah satu burung pemangsa yang terdapat di Indonesia adalah Elang Jawa (Nisaetus bartelsi). Taman Nasional Gunung Halimun Salak (TNGHS) adalah salah satu taman nasional yang ada di Indonesia. TNGHS merupakan salah satu habitat bagi Elang Jawa, hal ini dikarenakan kondisinya yang bisa dikatakan masih cukup baik dan data-data mengenai burung Elang Jawa di Kawasan TNGHS masih belum memadai. Oleh karena itu, diperlukan eksplorasi mengenai habitat populasi Elang Jawa di Kawasan TNGHS. Penelitian ini bertujuan untuk menjelaskan habitat dan sarang Elang Jawa yang meliputi lokasi, jenis pohon dan ciri-ciri pohon yang digunakan sebagai tempat meletakan sarang di TNGHS. Hal ini berguna untuk memberikan informasi tentang habitat sarang Elang Jawa pada Kawasan tersebut. Metode yang digunakan yaitu survei, pemantauan sarang, wawancara, pengumpulan dan analisis data. Berdasarkan hasil pengamatan $N$. bartelsi, menggunakan pohon Litsea cordata (Huru) dengan ketinggian $\pm 40-60$ meter sebagai sarangnya, dan pohon Schima wallichii (Puspa) untuk bertengger.
\end{abstract}

Kata Kunci: Elang Jawa; Habitat; Sarang; TNGHS

\section{ABSTRACT}

One of the birds of prey found in Indonesia is the Javan Hawk Eagle (Nisaetus bartelsi). Mount Halimun Salak National Park (TNGHS) is one of the national parks in Indonesia. TNGHS is one of the habitats for Javanese eagles. This is because the conditions are still quite good and data on Javanese eagles in the TNGHS area are still inadequate. Therefore, it is necessary to explore the habitat of the Javan hawk population in the TNGHS area. This study aims to explain the habitat and nest of Javanese eagles which include location, tree species and tree characteristics used as a place to place nests in TNGHS. This is useful for providing information about the Javan hawk nest habitat in the area. The methods used are surveys, nest monitoring, interviews, data collection and analysis. Based on the observations of $N$. bartelsi, using the tree Litsea cordata (Huru) with a height of $\pm 40-60$ meters as a nest, and the tree Schima wallichii (Puspa) for perching.

Keywords: Javan hawk eagle; Habitat; Nest; TNGHS

\section{PENDAHULUAN}

Kelompok burung (Aves) merupakan jenis fauna dengan keanekaragaman hayati yang cukup tinggi di Indonesia. Indonesia diketahui memiliki 1.598 jenis burung yang tersebar di berbagai pulau, diantaranya adalah jenis burung pemangsa. Burung pemangsa menempati posisi sebagai konsumen satu atau konsumen teratas dalam urutan rantai makanan (Prasetyo 2002).
Apabila terdapat gangguan terhadap populasi burung pemangsa, maka akan terjadi gangguan pada ekosistem rantai makanan. Selain itu, kepekaannya terhadap lingkungan menjadikan mereka sebagai indikator lingkungan yang sehat. Jika kondisi lingkungan terganggu, maka 90\% kemungkinan burung pemangsa akan punah. Berdasarkan peran tersebut maka burung 
pemangsa dikategorikan sebagai satwa yang dilindungi (Azmi et al. 2016).

Salah satu burung pemangsa yang terdapat di Indonesia adalah Elang Jawa $(N$. bartelsi). Sesuai dengan namanya, Elang Jawa merupakan burung pemangsa endemik di Pulau Jawa. Layaknya burung pemangsa, Elang Jawa merupakan burung pemangsa yang menduduki konsumen teratas (top predator) dalam rantai makanan. Elang Jawa ini mengontrol populasi hewan lain yang menjadi mangsanya di alam. Akan tetapi, keberadaan mereka saat ini dalam kondisi populasi yang tidak baik (Sitorus dan Hernowo 2016).

Taman Nasional Gunung Halimun Salak (TNGHS) adalah salah satu taman nasional yang ada di Indonesia. TNGHS merupakan salah satu habitat bagi Elang Jawa, Hal ini dikarenakan kondisinya yang bisa dikatakan masih cukup baik (TNGHS 2017). Data-data mengenai ekologi sarang Elang Jawa di kawasan TNGHS masih belum cukup memadai, beberapa diantaranya hanya menyajikan data di wilayah yang berbeda, seperti di Alas Purwo dan di wilayah Gunung Gede Pangrango (Sitorus dan Hernowo 2016). Oleh karena itu, diperlukan sekali diadakan eksplorasi mengenai Habitat Populasi Elang Jawa di Kawasan TNGHS ini (Ridwan dan Rusli, 2014).

Tujuan pengamatan ini adalah untuk menjelaskan habitat dan sarang Elang Jawa yang meliputi: lokasi, jenis pohon dan ciriciri pohon yang digunakan sebagai tempat meletakan sarang di TNGHS. Hal ini berguna untuk memberikan informasi tentang habitat sarang Elang Jawa pada Kawasan tersebut.

\section{METODE}

\section{Lokasi dan waktu}

Observasi dilakukan selama 13 hari pada bulan Februari 2020 yang berlokasi di Bumi Perkemahan Sukamantri, Bogor, Jawa Barat. Frekuensi waktu yaitu 5 jam dalam satu hari sehingga diperoleh dalam frekuensi jam adalah 65 jam.

\section{Alat dan Bahan}

Alat dan bahan yang digunakan dalam penelitian ini adalah binokular, monokular, GPS (Global Positioning System), alat tulis, tally sheet atau logbook, alat ukur lingkungan (meteran), kamera digital, handphone dan lensa tele.

\section{Metode Pengumpulan Data}

Pengambilan data lapangan dilakukan dengan cara menggunakan metode direct observation. Metode direct observation yang dilakukan adalah metode monitoring secara bersama oleh beberapa orang peneliti terhadap obyek yang sama untuk mendapatkan hasil yang lebih efektif. Kegiatan monitoring ini dilakukan selama 12 hari dengan durasi waktu dalam satu hari yaitu 5-6 jam. Metode dilakukan dengan menempatkan beberapa peneliti di beberapa titik tertentu yang telah ditentukan sebelumnya. Setiap peneliti yang berada di masing-masing titik mengamati dan mencatat secara rinci obyek yang diamati seperti pohon dan sarang Elang Jawa.

Pengambilan data lapangan, seperti pohon sarang dan sarang Elang Jawa digunakan dengan metode penelusuran secara langsung ke dalam hutan dengan monitoring sarang yaitu mengamati jenisjenis pohon yang dijadikan sarang. Selanjutnya, dilakukan penentuan titik pengamatan (points count) dengan kondisi titik pandang yang paling optimum ke arah pohon sarang dan selanjutnya dilakukan pemantauan secara berkala untuk memantau kondisi sarang dan aktivitas Elang Jawa di sekitar sarang.

\section{Analisa Literatur}

Metode analisis literatur dilakukan dengan pembimbing lapangan untuk memenuhi data ketinggian pohon sarang, diameter pohon, ukuran sarang dan bahan sarang Elang Jawa, sehingga mendapatkan informasi mengenai data kuantitas terhadap habitat sarang Elang Jawa. 


\section{Analisa Data}

Dilakukan analisis terhadap pola ruang yang digunakan Elang Jawa pada saat beraktivitas. Menurut Purbahapsari (2013), pembagian ruang tajuk pohon dibagi menjadi dua ruang yaitu secara vertikal dan horizontal. Pada vertikal dibuat menjadi ruang I, II dan III, dan pada horizontal dibagi menjadi ruang $\mathrm{A}, \mathrm{B}$ dan $\mathrm{C}$. Hal ini didasarkan pada model arsitektur pohon, dan selanjutnya dianalisis secara deskriptif (Gambar 1).

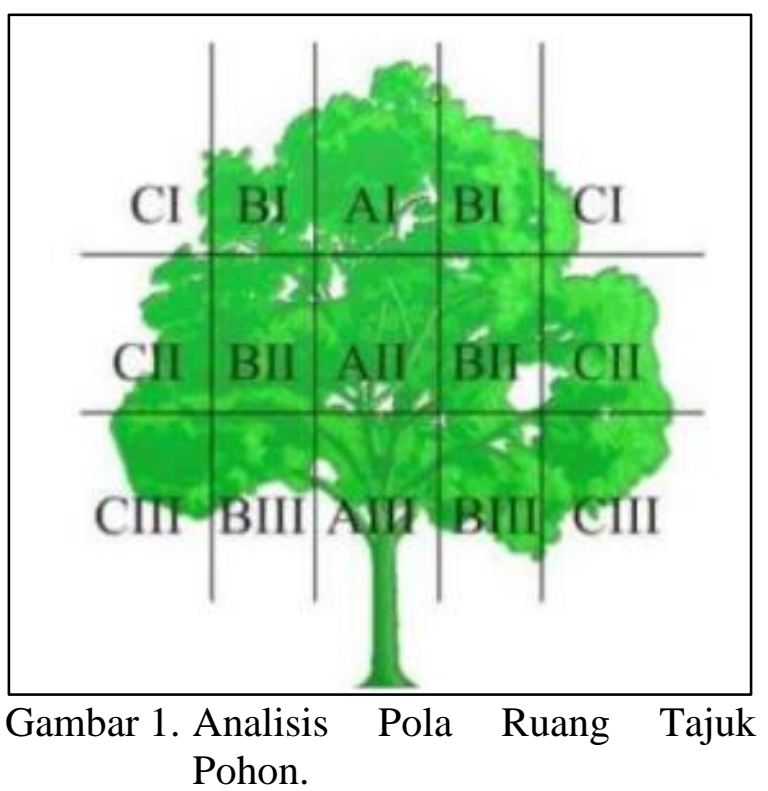

\section{HASIL DAN PEMBAHASAN}

Pengamatan dilakukan pada titik pengamatan $137^{\circ} \mathrm{TG}-6^{\mathrm{O}} 40$ ' $38^{\prime}$ 'S-106 ${ }^{\circ} 45^{\prime} 12$ " T. Hasil pengamatan menunjukan bahwa pada sarang burung Elang Jawa aktif terdapat populasi burung Elang Jawa yang sedang melakukan proses breeding, dan informasi ini diperoleh setelah melakukan hasil survei yang dilakukan pada tanggal 5 September 2020. Terdapat 3 individu Elang Jawa, yaitu 2 dewasa dan 1 Elang muda yang sedang melakukan aktivitas soaring di sekitar sarangnya. Aktivitas didukung dengan kondisi lingkungan sekitar yaitu adanya potensi flora jenis pohon hutan hujan dataran rendah (1,000-1,500 mdpl) yang masih melimpah di sekitar sarang (TNGHS 2017).
Berdasarkan hasil pengamatan, Elang Jawa lebih menyukai lokasi hutan yang berada di punggungan pegunungan yang berada di dekat lembah. Pohon yang digunakan Elang Jawa di lokasi pengamatan yaitu pohon $L$. cordata atau dikenal dengan nama daerah pohon Huru, dengan bentuk arsitektur pohon Rauh. Posisi pohon sarang ini berada pada titik $6^{\circ} 40$ ' 44.7" LS $106^{\circ}$ 45' 17.4" BT dan pada ketinggian 898,56 mdpl (Gambar 2). Lokasi ini berada di sekitar dari wilayah camping ground bumi perkemahan Sukamantri, Resort 1.

Menurut Ridwan dan Rusli (2014), Elang Jawa menggunakan pohon Castanopsis argentea (Pohon Saninten) yang ditumbuhi banyak Liana pada batang utamanya untuk bersarang. Pohon yang dipilih merupakan pohon yang paling tinggi di antara pohon lainnya, serta memiliki pandangan terbuka ke arah lembah sehingga memudahkan pasangan Elang Jawa untuk keluar masuk dari sarang dan mengawasi dari tempat lain. Biasanya pohon yang dipilih oleh Elang Jawa memiliki ketinggian 土40-60 meter dari tanah, dan biasanya sarang diletakan pada tumpukan epifit pada cabang kedua dengan ketinggian \pm 30 meter dari permukaan tanah. Material sarang yang dipakai oleh Elang Jawa terdiri dari rantingranting pohon, daun-daunan yang masih hijau yang secara periodik setelah daun mengering akan diganti dengan ranting dan daun-daunan yang baru.

Berbeda dengan penelitian yang sebelumnya, menurut Ridwan dan Rusli (2014) bahwa pohon sarang Elang Jawa yang digunakan pada tahun 2018 hingga 2020 ditemukan pada hutan alam dataran rendah. Pohon Huru merupakan salah satu keanekaragaman flora yang berada di kawasan TNGHS. Hasil penelitian yang dilakukan oleh Uji (2002) memberikan informasi bahwa, terdapat 275 tumbuhan yang dilestarikan dikawasan TNGHS. Adapun klasifikasi spesies pohon ini yaitu, Divisi Spermatophyta, Sub Divisi Angiospermae, Kelas Dicotyledonae, Ordo Polycarpicae, Familia Lauraceae, Genus Litsea dan Spesies Litsea cordata. 


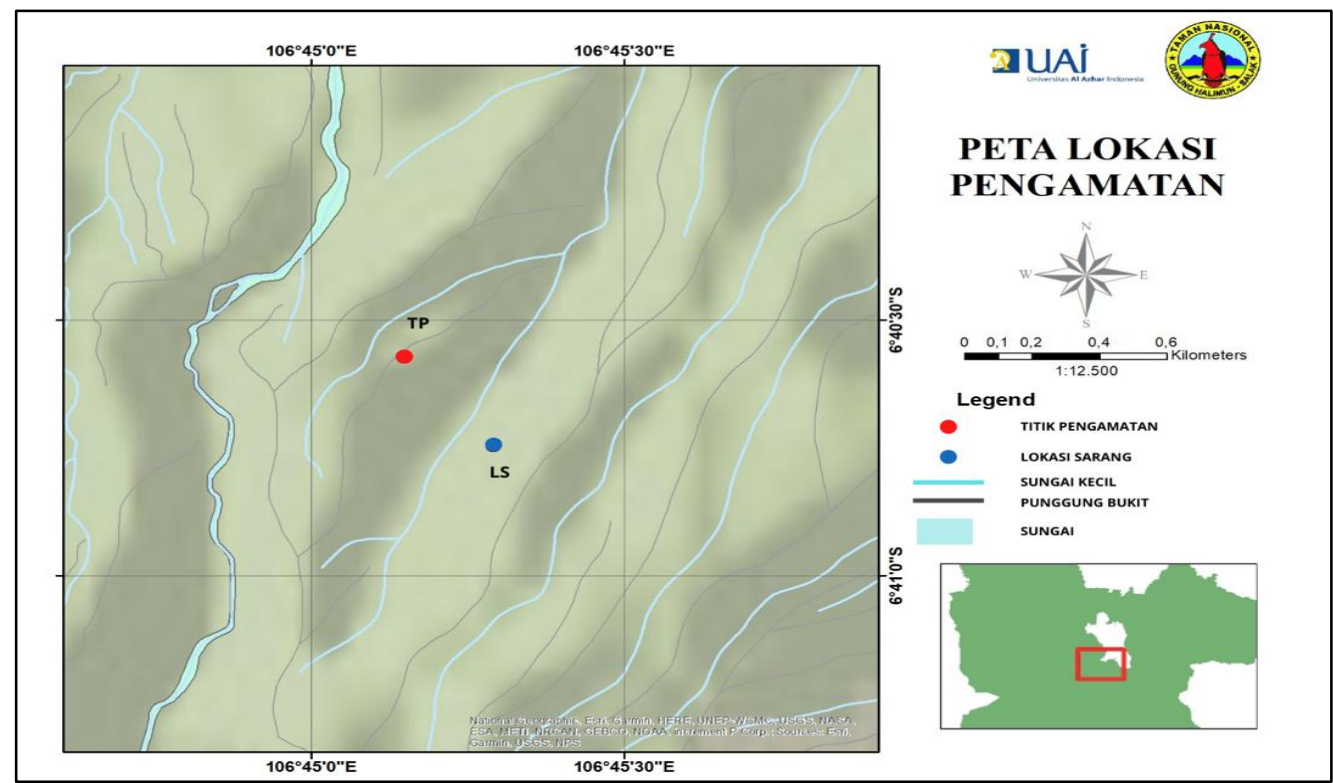

Gambar 2. Peta Lokasi Titik Pengamatan dan Lokasi Sarang Elang Jawa di Bumi Perkemahan Sukamantri.

Tabel 1. Karateristik Pohon Utama Habitat Elang Jawa

\begin{tabular}{|c|c|c|}
\hline \multirow[t]{2}{*}{ Keterangan } & \multicolumn{2}{|c|}{ Pohon Utama } \\
\hline & Pohon Sarang & Pohon Monitoring \\
\hline Jenis Pohon & Litsea cordata (Pohon Huru) & Schima wallichii (Pohon Puspa) \\
\hline Jumlah & 1 Pohon & 1 Pohon \\
\hline Fungsi & Sebagai tempat sarang & $\begin{array}{l}\text { Tempat untuk memonitoring } \\
\text { sarang, teritori dan memonitoring } \\
\text { mangsanya. }\end{array}$ \\
\hline Lokasi & $\begin{array}{l}\text { Menghadap ke area terbuka dan } \\
\text { terletak di punggung } \\
\text { pegunungan. }\end{array}$ & $\begin{array}{l}\text { Menghadap ke area terbuka, } \\
\text { dengan bentuk pohon yang terbuka, } \\
\text { agar mempermudah melakukan } \\
\text { monitoring }\end{array}$ \\
\hline Morfologi & $\begin{array}{l}\text { Berbatang tegak, memiliki } \\
\text { percabangan yang sedikit dan } \\
\text { agak rimbun. }\end{array}$ & $\begin{array}{l}\text { Batang tegak dan percabangan } \\
\text { sedikit. }\end{array}$ \\
\hline Catatan & & 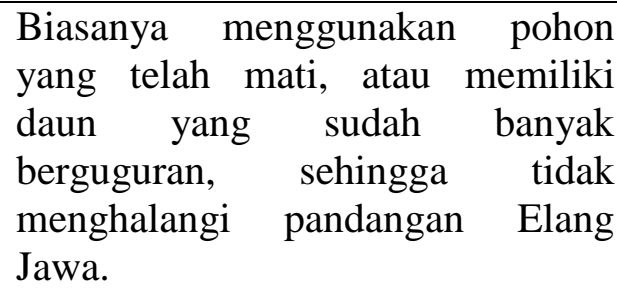 \\
\hline
\end{tabular}

Pada dunia industri, pohon ini dikenal dengan nama kayu medan, kayu ini memiliki berat jenis $\pm 0,40-0,86$ dan termasuk ke dalam kayu kelas kuat II-III, serta awet kelas III. Kayu ini memiliki karakteristik berwarna keputihan dengan memiliki permukaan batang yang halus dan berwarna abu-abu keputihan, serta diameter yang bervariasi. Kayu ini banyak digunakan untuk berbagai macam keperluan seperti untuk keperluan perkakas rumah tangga, dan merupakan jenis kayu untuk bangunan 
perkapalan yang digunakan sebagai papan geladak atau bagian konstruksi diatas garis air kapal seluruh Indonesia (Sitanggang et al. 2019).

Pada setiap habitat Elang Jawa yang ditemukan di TNGHS blok Sukamantri, teramati terdapat dua jenis pohon yang memiliki fungsi khusus dalam aktivitas hidup Elang Jawa, yaitu: pohon sarang dan pohon monitoring. Menurut Prasetyo (2002), masing-masing pohon memiliki karakteristik dan fungsi tersendiri dalam kehidupan Elang Jawa. Pohon sarang yaitu pohon $L$. cordata (Pohon Huru) pada lokasi pengamatan memiliki beberapa karakteristik utama diantaranya, yaitu: berbatang tegak, memiliki percabangan yang sedikit dan memiliki daun yang sedikit rimbun, dan hanya terdapat satu pohon sebagai lokasi sarang Elang Jawa dan menghadap ke area terbuka. Selanjutnya, pohon monitoring yaitu Schima wallichii (Pohon Puspa) memiliki karakteristik yang tidak berbeda jauh dengan pohon sarang, yaitu: memiliki batang yang tegak dan memiliki percabangan pohon sedikit, menghadap ke area terbuka dengan bentuk pohon yang terbuka, dengan tujuan mempermudah melakukan monitoring. Biasanya Elang Jawa menggunakan pohon yang telah mati atau dengan kondisi daun yang sudah banyak berguguran, sehingga tidak mengahalangi pandangan Elang Jawa (Tabel 1).

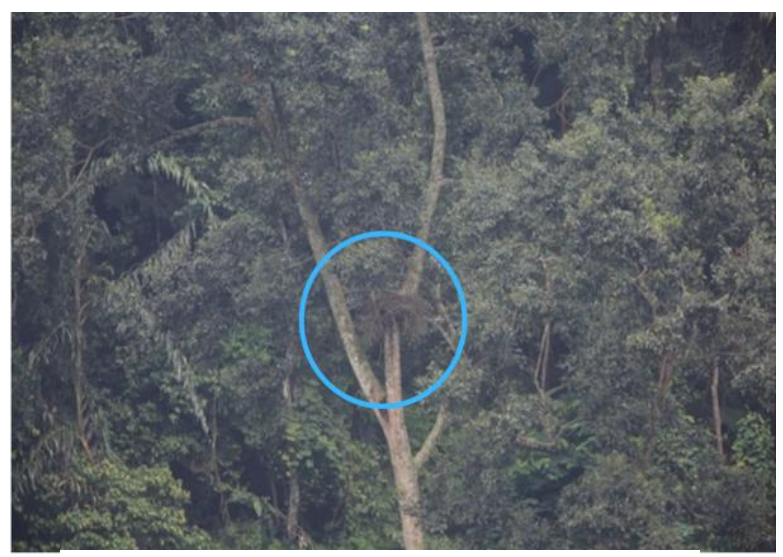

A
Berdasarkan karakteristik yang telah disebutkan dapat dikatakan bahwa Elang Jawa menggunakan pohon ini dikarenakan memiliki batang yang kuat untuk menopang berat massa dari sarangnya, selain itu, pohon Huru yang digunakan merupakan pohon emergent tree yaitu pohon yang memiliki tajuk yang terbuka dan memiliki cabang yang besar sehingga memudahkan Elang Jawa untuk membangun sarang, dan emergent tree akan memudahkan Elang Jawa untuk membidik dan memperoleh mangsa. Selain itu, mempermudah Elang Jawa untuk keluar masuk dari tajuk pohon dan untuk pemeliharaan keselamatan anaknya (Sitanggang et al. 2019).

L. cordata atau dikenal dengan nama lokal yaitu pohon Huru, pada lokasi pengamatan memiliki beberapa karakteristik, diantaranya; memiliki ketinggian pohon $\pm 40-60$ meter dengan ketinggian sarang berada pada ketinggian \pm 30 meter dari tanah. Kondisi sarang seperti ini mempermudah Elang Jawa untuk memantau mangsanya dan untuk menghindari gangguan dari hewan dan manusia. Elang Jawa membangun sarangnya membutuhkan waktu $\pm 1-2$ bulan hingga sarang tersebut dapat digunakan, hal ini dikarenakan Elang Jawa membutuhkan waktu untuk mencari ranting-ranting yang kering sesuai dengan kebutuhannya (Prasetyo 2002).

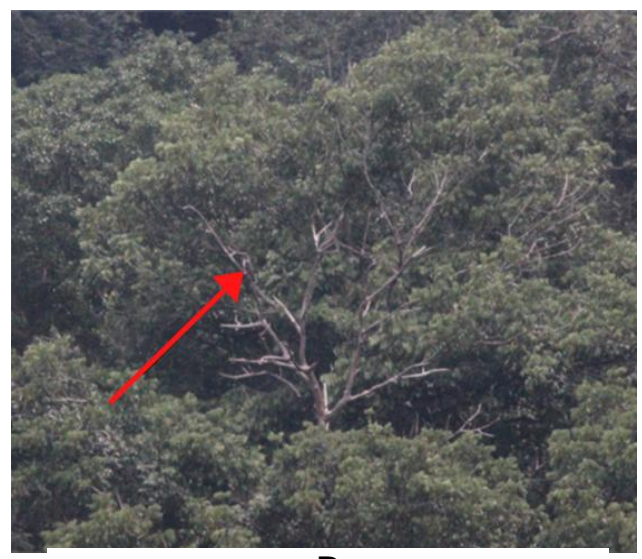

B

Gambar 3. Sarang Elang Jawa (Nisaetus bartelsi) Bumi Perkemahan Sukamantri, Bogor, Jawa Barat. A. Lokasi Pohon sarang; B. Lokasi pohon bertengger. 
Sarang Elang Jawa sendiri terdiri dari ranting-ranting pohon, kemudian dilapisi dengan daun-daun basah sebagai alasnya. Sarang Elang Jawa yang berada di pohon Huru ini memiliki diameter $\pm 1,4 \mathrm{~m}$, jari-jari $70 \mathrm{~cm}$ dan kedalaman sarang $\pm 3 \mathrm{~m}$ dengan memiliki bentuk kerucut terbalik (Gambar 3). Tingkat kesesuaian habitat bagi suatu spesies akan berbeda antara satu spesies dengan spesies yang lainnya, hal ini dikarenakan setiap spesies memiliki karakteristik komponen habitat yang berbeda-beda untuk mempertahankan hidupnya (Prasetyo 2002).

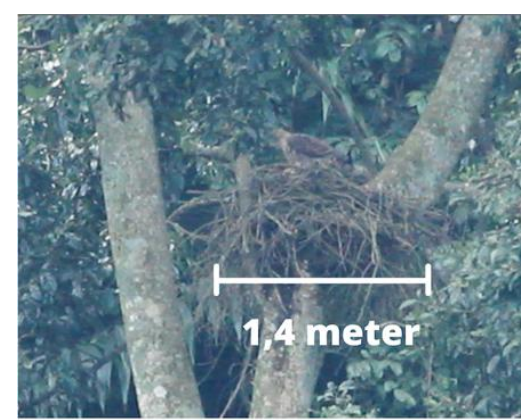

Gambar 4. Ukuran Sarang Elang Jawa.

Beberapa penelitian yang dilakukan sebelumnya, menyebutkan bahwa Elang Jawa cenderung lebih suka menempati habitat hujan tropis primer dan sekunder dengan memiliki curah hujan yang relatif tinggi. Kedua tipe habitat tersebut dimanfaatkan oleh Elang Jawa sebagai areal untuk berburu dan bersarang. Pada penelitian ini Elang Jawa menggunakan ruang tajuk yang dekat dengan batang utama yaitu B (I, II dan III) untuk perilaku istirahat, mengintai mangsa dan membangun sarang dengan pembagian ilustrasi ruang tajuk seperti (Gambar 5) (Azmi et al. 2016).

Hal ini dikarenakan pada ruang tajuk tersebut Elang Jawa lebih nyaman untuk berisitirahat, memiliki ruang dan jarak pandangan yang luas sehingga akan mempermudah pergerakan Elang Jawa. Afianto (1999) menyebutkan bahwa pandangan dari sarang adalah terbuka yang diperuntukan untuk memudahkan Elang Jawa terbang meluncur (gliding) keluar masuk pohon sarang tanpa mengepakan sayap, dan memonitoring keberadaan mangsa dan individu lain di sekitar pohon sarang. Cabang yang dekat dengan batang utama memiliki ukuran $\pm 90^{\circ}$, ternaungi oleh tajuk, dan cabang tidak rapat oleh dedaunan dan cabang kuat untuk menopang tubuh Elang Jawa. Sitorus \& Hernowo (2016) menyatakan bahwa Elang Jawa bertengger pada bagian tengah pohon karena menyediakan cabang yang kuat untuk menopang tubuh Elang Jawa (Gambar 4).

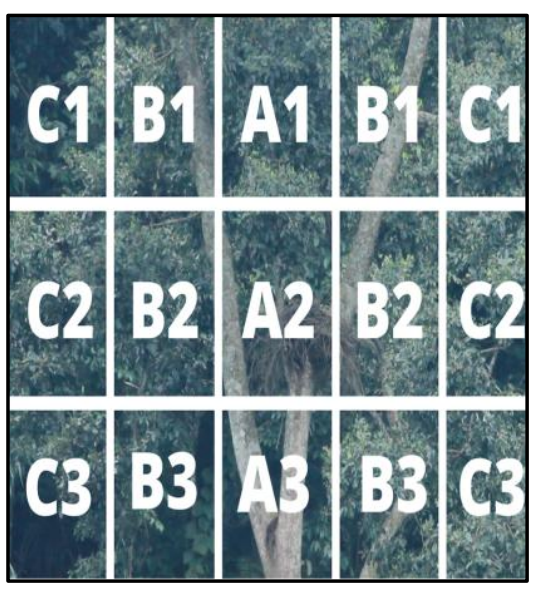

Gambar 5. Pembagian ruang tajuk pohon.

Selanjutnya, jenis-jenis pohon yang dipilih oleh Elang Jawa sebagai tempat beristirahat dan makan memiliki bentuk arsitektur pohon Rauh. Menurut Sitanggang et al. (2019), arsitektur model Rauh merupakan model dengan bentuk pohon yang memiliki batang monopodial dengan percabangan ritmik. Memiliki pola percabangan monopodial dan orthotropy, pola percabangan ini antara batang dengan bunga saling berhubungan, dimana pada umumnya batang mengarah secara lateral. Percabangan dengan orthotopic akan membantu meningkatkan aliran batang, karena cabang-cabang yang tumbuh secara vertikal akan berfungsi sebagai penampung air hujan yang selanjutnya dialirkan ke batang utama. Kemudian Elang Jawa juga menggunakan cabang pohon yang tidak berdaun untuk bertengger, hal ini akan memudahkan Elang Jawa untuk melakukan monitoring terhadap sekitarnya, dan melihat mangsanya. Sitorus dan Hernowo (2016) menyatakan bahwa jenis-jenis Elang 
menyukai pohon yang sudah mati namun masih berdiri dengan tegak (Gambar 3b).

Banyaknya populasi pohon Huru di titik pengamatan menjadikan pohon ini menjadi pohon yang mendominasi wilayah ini. Menurut Uji (2002), kelompok tumbuhan Lauraceae di wilayah TNGHS terdiri dari beberapa spesies diantaranya, yaitu: Marchilus rimosa (Huru mentek), Lindera bibracteata (Huru ki teja), Litsea accedentoides (Huru payung), Litsea angulata (Huru merang), Litsea cubeba (Huru lemo), serta Litsea elleptica (Huru batu), Litsea mappacea (Huru tales), Litsea noronhqe (Huru kapas), Litsea oppositifolia (Huru beureum), Litsea resinosa (Huru minyak), Neolitsea javanica (Huru bodas), dan Phoebe elliptica (Huru gempol).

\section{KESIMPULAN}

Berdasarkan pengamatan yang telah dilakukan, dapat disimpulkan bahwa habitat pohon yang digunakan burung Elang Jawa untuk bersarang dan bertengger memiliki karakteristik diantaranya yaitu: lokasi pohon yang berada di punggungan hutan dekat dengan lembah, memiliki ketinggian $\pm 40-60$ meter dengan posisi sarang berada pada ketinggian \pm 30 meter dari daratan, merupakan pohon emergent tree yaitu pohon yang menjulang tinggi, memiliki arsitektur model Rauh dengan batang monopodial dan percabangan ritmik, dan batang mengarah secara lateral.

\section{UCAPAN TERIMAKASIH}

Penulis juga mengucapkan terimakasih kepada Saudara Yopi Suhendar selaku pendamping dan pembimbing lapangan serta tim yang telah membantu selama kegiatan berlangsung.

\section{DAFTAR PUSTAKA}

Afianto M (1999) Studi aspek ekologi Elang Jawa (Spizaetus bartelsi Stresemann 1924) di Gunung Salak. Bogor: Institut Pertanian Bogor.

Azmi N, Syartinilia, Mulyani Y (2016) Model Distribusi Spasial Habitat Elang
Jawa (Nisaetus bartelsi) yang Tersisa Di Jawa Barat. Media Konservasi. 9-18.

Istomo, Sari PN (2019) Penyebaran Dan Karakteristik Habitat Jenis Rasamala (Altingia excelsa Noronha) di Taman Nasional Gunung Halimun Salak. Journal of Natural Resources and Environmental Management, 608-625.

Purbahapsari AF (2013) Penggunaan Habitat Koridor Halimun Salak Oleh Elang Ular Bido (Spilornis cheela Latham, 1790) Di Taman Nasional Gunung Halimun Salak. IPB, Bogor.

Prabowo SA, Basuni S, Suharjito D (2010) Konflik Tanpa Henti: Permukiman dalam Kawasan Taman Nasional Halimun Salak. JMHT, 137-142.

Prasetyo DK (2002) Studi Habitat Sekitar Elang Jawa (Spizaetus bartelsi) Di Kawasan Cibulao Taman Nasional Gede-Pangrango Jawa Barat. Universitas Diponegoro, Semarang.

Ridwan I, At M, Rusli AR (2014)

Pemantauan Ekologi Sarang Elang Jawa (Spizaetus bartelsi) Di Wilayah Hutan Cikaniki Taman Nasional Gunung Halimun Salak. Jurnal Nusa Sylva, 4346.

Sitanggang E, Manurung TF, Rifanjani S (2019) Identifikasi Model Arsitektur Jenis Pohon Famili Lauraceae Di Kawasan Arboretum Sylva Universitas Tanjungpura Pontianak. Jurnal Hutan Lestari, 1328-1337.

Sitorus DN, Hernowo J (2016) Habitat dan Perilaku Elang Jawa (Nisaetus bartelsi) di STPN 1 Tegal Limo Taman Nasional Alas Puwo, Jawa Timur. Media Konservasi, 278-285.

Uji T (2002) Keanekaragaman dan Potensi Flora di Gunung Halimun dan Sekitarnya di Taman Nasional Gunung Halimun. Berita Biologi, 1-12.

Taman Nasional Gunung Halimun Salak (2017) Rencana Pengelolaan Jangka Panjang Taman Nasional Gunung Halimun Salak Tahun 2018-2027. Kabandungan: Balai Taman Nasional Gunung Halimun Salak. 